\title{
GAMBARAN TINGKAT ANSIETAS DAN MEKANISME KOPING PADA MAHASISWA KEPERAWATAN DALAM MENGHADAPI UJIAN PRAKTEK LABORATORIUM
}

\author{
Daesy Kristiana Lau ${ }^{1}$, Venti Agustina ${ }^{1 *}$, Heri Setiawan ${ }^{2}$ \\ ${ }^{1}$ Program Studi Ilmu Keperawatan, Fakultas Kedokteran dan Ilmu Kesehatan, Universitas Kristesn \\ Satya Wacana \\ ${ }^{2}$ Rumah Sakit Jiwa Prof. Dr. Soerojo Magelang \\ *venti.agustina@uksw.edu
}

\begin{abstract}
ABSTRAK
Mahasiswa rentan mengalami ansiestas salah satu yang menjadi sumber ansiestas bagi mahasiswa yaitu ujian. Ujian merupakan bagian dari evaluasi mahasiswa terhadap proses pembelajaran dalam satu semester. Ujian tidak hanya teori tetapi juga praktek, praktek tidak hanya di rumah sakit atau klinik tetapi juga dilakukan di laboraturium. Praktek laboratorium akan dilewati mahasiswa dengan persyaratan yang ditentukan seperti waktu, kerapihan, cepat dan tepat serta harus dilakukan secara lengkap tanpa terlewati satu unsur pun dalam waktu uji yang singkat. Hal ini menjadi salah satu stimulus timbulnya ansiestas pada mahasiswa. Tujuan penelitian ini untuk mengetahui gambaran tingkat ansietas dan mekanisme koping pada mahasiswa keperawatan dalam menghadapi ujian praktek laboratorium. Desain penelitian yang digunakan adalah penelitian kuantitatif deskriptif cross sectional. Populasi dalam penelitian sebanyak 150 orang yang pernah dan sedang melakukan praktek laboratorium. Waktu pengambilan data pada bulan Februari-Maret 2019. Teknik pengambilan sampel menggunakan teknik purposive sampling,instrument yang digunakan kuesioner ZSAS dan kuesioner COPE SCALE. Analisa data univariat dengan distribusi frekuensi. Hasil penelitian menunjukkan sebagian besar mahasiswa keperawatan mengalami ansiestas dalam kategori normal dengan mekanisme koping terbanyak yang digunakan berfokus pada emosi atau Emotional Focused Coping.
\end{abstract}

Kata kunci: ansiestas, mekanisme koping, mahasiswa keperawatan, ujian praktek laboratorium

\section{DESCRIPTION OF ANSIETHIC LEVELS AND COOPERATING MECHANISMS IN NURSING STUDENTS IN FACING LABORATORY PRACTICE EXAMS}

\begin{abstract}
Students are vulnerable to experiencing anxiety. One of the sources of anxiety for students is the exam. The exam is part of a student's evaluation of the learning process in one semester. Exams are not only theory but also practice, practice not only in hospitals or clinics but also in laboratories. Laboratory practice will be passed by students with the specified requirements such as time, neatness, fast and precise and must be done in full without missing any elements in a short test time. This has become one of the stimulus for anxiety on students. The purpose of this study was to determine the level of anxiety and coping mechanisms in nursing students facing laboratory practice exams. The research design used was descriptive cross sectional descriptive study. The population in the study were 150 people who had and were doing laboratory practice. Data collection time is February-March 2019. The sampling technique uses purposive sampling technique, the instrument used is the ZSAS questionnaire and the COPE SCALE questionnaire. Univariate data analysis with frequency distribution. The results showed that most nursing students experienced anxiety in the normal category with the most coping mechanisms used to focus on emotions or Emotional Focused Coping.
\end{abstract}

Keywords: anxiety, coping mechanism, nursing students, laboratory practice exams

PENDAHULUAN

International Health Metrics and Evaluation (IHME) mengungkapkan bahwa presentasi penduduk penderita gangguan mental terbesar atau yang paling banyak adalah di Greenland yang dalam wilayah tersebut ada $22,14 \%$ atau sekitar 12.440 jiwa dari total populasi, 
Australia menduduki peringkat kedua $(21,73 \%$ dari populasi) dan Amerika Serikat menduduki peringkat ketiga $(21,56 \%)$ dari hal tersebut gangguan mental dengan prevalensi tertinggi adalah penyakit kecemasan atau anxiety yang berlebihan. Dalam bahasa Indonesia terdapat banyak kata yang menunjukan emosi tertentu misalnya sedih, marah, bahagia, khawatir, risau, takjub dan gembira dan salah satunya cemas (Saam dan Wahyuni, 2012). Penderita gangguan ansiestas mencapai 5\% dari jumlah penduduk dunia sementara perbandingan antara penderita gangguan ansiestas pada wanita dan pria yaitu 2 banding 1 dan diperkirakan sebanyak 2\%-4\% dari penduduk dunia pernah mengalamai gangguan ansiestas (Sjahrir, 2008). Data hasil Riskesdas 2013 menunjukan prevalensi gangguan mental emosional seperti depresi dan ansiestas yang merupakan gejala-gejala dari setiap individu yang dapat ditunjukan, untuk umur 15 tahun keatas mencapai sekitar 14 juta orang dan $6 \%$ dari jumlah penduduk Indonesia.

Menurut Nanda 2015 ansiestas merupakan bentuk respon terhadap stimulus tertentu yang tidak diinginkan oleh siapapun yang dapat terjadi dimanapun dan kapanpun karena dalam hal ini ansiestas tidak mengenal jenis kelamin, suku atau ras dan batas usiabegitu juga menurut Nursalam (2012) cemas merupakan emosi dan pengalaman subjektif individu yang sulit untuk diobservasi secara langsung akan tetapi dapat diidentifikasi ansiestas ini melalu perubahan tingkah laku. Ansiestas yang dialami akan menentukan bagaimana mekanisme koping seseorang dalam mengatasi masalah tersebut baik mekanisme koping adaptif atau maladaptif, individu yang memiliki mekanisme koping adaptif akan lebih efektif untuk mengurangi atau meredam ansiestas sebaliknya jika individu menggunakan mekanisme koping maladaptif bisa memperburuk keadaan atau individu tersebut mempunyai potensi untuk terjadinya sakit (Sholeh, 2012). Perilaku mekanisme koping seseorang dapat menunjukan maladaptif atau tidak efektif jika tidak dapat mengatasi ansiestas secara sehat (Keliat etal, 2011) dan tingkat ansiestas yang meningkat dapat menyebabkan gangguan jiwa (Essau, 2010)

Mekanisme koping adalah usaha yang dilakukan individu untuk mengatasi stres psikologis dalam hal ini ansiestas (Potter \&
Perry, 2010). Koping menjadi hal penting dalam menentukan respon yang dapat muncul apakah adaptif atau maladaptif dari setiap kehidupan individu (Dardas, 2013) dengan melihat strategi koping yang digunakan oleh responden apakah berfokus pada emotional focused coping atau promblen focused coping dimana mekanisme koping yang positif atau dapat dikatakan koping efektif bila menempatitempat yang sentral terhadap ketahanan tubuh dan daya penolakan tubuh terhadap gangguan maupun serangan suatu penyakit baik bersifat fisik atau psikis dan social (Nursalam \& Ninuk 2013). Penelitian terkait mekanisme koping pada mahasiswa menunjukan $74,7 \%$ mahasiswa memiliki mekanisme koping yang adaptif dalam menghadapi Objective Structured Clinical Examination (RafikiD, 2017), selain itu penelitian terkait mekanisme koping dalam mengatasi stress pada mahasiswa Akademi Keperawatan Dapartemen Kesehatan RI tingkat satu Meulaboh mengatakan mayoritas mahasiswa memiliki mekanisme yang baik dalam menyelesaikan masalahanya yaitu sebanyak 71 responden dengan persentase (65.7\%) dan selebihnya 37 responden dengan persentase $(34.3 \%)$ yang memiliki mekanisme koping yang kurang (Oli, 2013). Adapun penelitian yang dilakukan oleh Syarifah, S (2013) menyatakan bahwa mahasiswa juga rentan mengalami ansiestas dengan tuntutannya setiap hari seperti tugas, perkuliahan, lingkungan belajar, praktikum dan ujian, salah satu yang menjadi sumber ansiestas bagi mahasiswayaitu ujian. Ujian merupakan bagian dari evaluasi mahasiswa terhadap proses pembelajaran atau materi belajar dalam satu semester (Basuki, 2015).

Dalam hal ini terkait ujian tidak hanya teori tetapi ada juga praktek, praktek ini tidak hanya di rumah sakit atau klinik tetapi juga dilakukan di laboraturium.Praktek laboratorium yang didalamnya terdiri dari simulasi dan ujian akan dilewati oleh mahasiswa dengan persyaratan yang ditentukan seperti waktu, kerapihan, cekatan dan diperkuat oleh penelitian Arief \& Sumarni yang menyatakan ujian praktek laboratorium harus dapat dilaksanakan secara cepat dan tepat serta harus dilakukan secara lengkap tanpa terlewati satu unsur pun dalam waktu uji yang singkat $( \pm 10$ menit tiap satu keterampilan) hal ini juga menjadi salah satu 
stimulus timbulnya ansiestas pada mahasiswa (Arief, 2013). Penelitian yang dilakukan oleh Syarifah mengatakan jika semakin tinggi level ansiestas yang dirasakan maka cenderung menghasilkan kebingungan dan distorsi persepsi. Distorsi tersebut dapat mengganggu belajar dengan menurunkan kemampuan memusatkan perhatian, menurunkan daya ingat, mengganggu kemampuan mengghubungkan satu hal dengan yang lain (Kaplan dkk, 2010).

Dari pengalaman yang dirasakan oleh peneliti dan beberapa studi pendahuluan seperti oleh Syarifah dan beberapa mahasiswa yang berhasil diwawancarai mengatakan bahwa saat ujian praktek berlangsung ansiestas yang dialami dapat membuat seseorang hilang fokus, tremor, lupa, gugup. Penelitian di atas juga didukung oleh teori Stuart yang mengatakan ada dua macam respon ansiestas yang bisa dialami oleh seseorang yaitu respon fisiologi terhadap ansiestas dan respon psikologi terhadap ansiestas, respon fisiologi yang sering kali muncul seperti jantung berdebar, rasa tertekan pada dada, perasaan panas atau dingin pada kulit, telapak tangan berkeringat, wajah terlihat tegang dan respon psikologi yang sering kali muncul dilihat dari perilaku yaitu gelisah, tremor, gugup, bicara cepat dan tidak ada koordinasi, menarik diri dan menghindar, begitu juga dapat memperngaruhi kognitifnya seperti gangguan perhatian, konsentrasi hilang, mudah lupa salah tafsir, bingung, khawatir yang berlebihan, obyektifitas menurun, afektifnya juga dapat terganggu seperti tidak sabar, tegang, tremor, gugup yang luar biasa, sangat gelisah dan respon tersebut juga mempengaruhi hasil yang didapatkan (Stuart, 2005).

Tujuan yang ingin dicapai dalam peneltian ini untuk mendeskripsikan gambaran karakteristik responden, tingkat ansiestas, mekanisme koping mahasiswa Fakultas Kedokteran dan Ilmu Kesehatan Program Studi Ilmu Keperawatan Universitas Kristen Satya Wacana dalam menghadapi ujian praktek laboratorium. Berdasarkan uraian diatas ansiestas dapat mempengaruhi tindakan yang dilakukan mahasiswa saat ujian berlangsung yang mana juga berdampak pada hasil ujian.Maka dari itu peneliti hendak mendeskripsikan bagaimana tingkat ansiestas dan mekanisme koping pada mahasiswa PSIK FKIK dalam menghadapi ujian praktek laboratorium melalui penelitian kuantitatif.

\section{METODE}

Desain penelitian ini adalah penelitian kuantitatif deskriptif cross sectional. Penelitian dilakukan pada bulan Februari-Maret 2019. Populasi yang digunakan ialah sebanyak 150 orang mahasiswa Program Studi Ilmu Keperawatan yang pernah dan sedang melakukan praktek di laboratorium. Jumlah populasi mahasiswa tingkat II (angkatan 2017) sebanyak 71 orang dan tingkat III (angkatan 2016) sebanyak 79 orang. Teknik pengambilan sampel menggunakan teknik purposive sampling.

Pengumpulan data menggunakan kuesioner Zung Self Rating Anxiety Scale (ZSAS)yang di adopsi dari penelitian yang dilakukan oleh Syarifah, S. peneliti tidak melakukan uji validitaskarena kuesioner yang di adobsi merupakan kuesioner baku sebagai alat ukur yang valid dan reliabel (Nursalam, 2013). Instrument ZSAS disusun berdasarkan tujuan literature dan dikembangkan berdasarkan gejala ansiestas dalam Diagnostic And Statistical Manual Of Mental Disorders dan sudah di uji validitas dengan menggunakan korelasi product moment dari Pearson dan memiliki nilai positif dan nilai $t$ hitung $>\mathrm{t}$ tabel dan kuesioner untuk menggali mekanisme koping yang diadopsi dari instrument Cope Scale yang disusun oleh Lazarus and Folkman sebanyak 20 dengan hasil ukur dinyatakan dalam $\mathrm{Z}^{\mathrm{PFC}}=\left(\mathrm{X}^{\mathrm{PFC}} \mathrm{M}^{\mathrm{PFC}}\right) / \mathrm{S}^{\mathrm{PFC}}$ dan $\mathrm{Z}^{\mathrm{EFC}}=\left(\mathrm{X}^{\mathrm{EFC}} \mathrm{M}^{\mathrm{EFC}}\right) / \mathrm{S}^{\mathrm{EFC}}$ kemudian skor $\mathrm{Z}$ ini yang akan digunakan untuk pengkategorian mekanisme koping menjadi PFC atau EFC. Analisa data dilakukan dengan analisa univariat yang mendeskripsikan variabel penelitian tingkat ansiestasnya dan mekanisme koping mahasiswa yang mengikuti ujian praktek laboratorium

\section{HASIL}

Penelitian ini dilakukan untuk mengkaji ansiestas dan mekanisme koping pada mahasiswa PSIK FKIK Univeritas Kristen Satya Wacana dengan jumlah responden 150 orang. 
Tabel 1.

Karakteristik responden Mahasiswa keperawatan $(\mathrm{n}=150)$

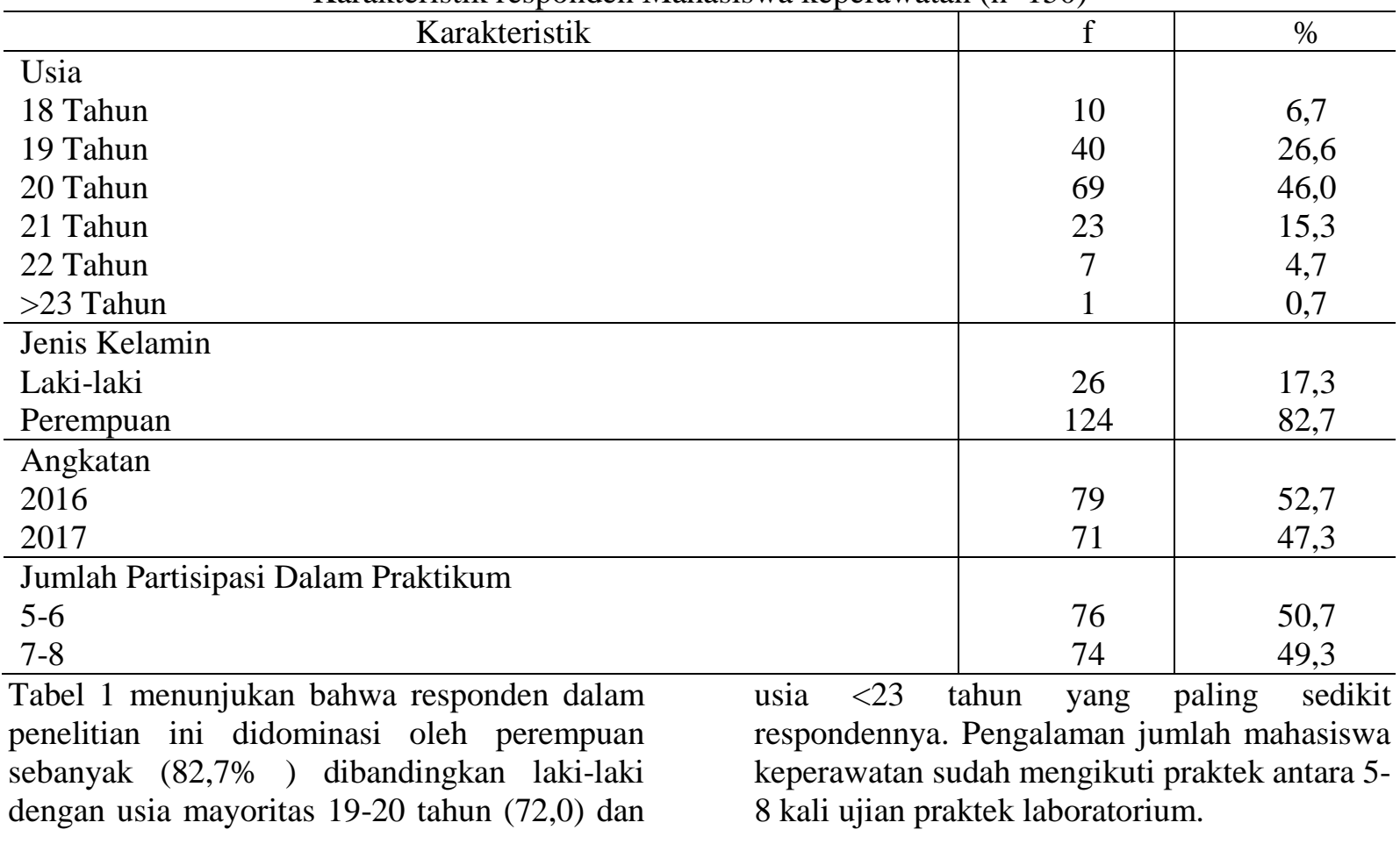

Tabel 2.

Tingkat ansiestas mahasiswa keperawatan $(\mathrm{n}=150)$

\begin{tabular}{c|c|c}
\hline Kategori Ansiestas & f & $\%$ \\
\hline Normal (20-44) & 121 & 80,7 \\
Ringan (45-59) & 29 & 19,3 \\
\hline
\end{tabular}

Tabel 2 menunjukan bahwa sebagian besar normal, sementara $19,3 \%$ responden yang responden masuk dalam kategori ansiestas masuk dalam kecemsan ringan.

Tabel 3.

Tingkat ansiestas berdasarkan usia Mahasiswa keperawatan $(n=150)$

\begin{tabular}{|c|c|c|c|c|}
\hline Variabel & \multicolumn{4}{|c|}{ Ansiestas } \\
\hline \multirow[t]{2}{*}{ Usia } & \multicolumn{2}{|c|}{ Normal } & \multicolumn{2}{|c|}{ Ringan } \\
\hline & f & $\%$ & $\mathrm{f}$ & $\%$ \\
\hline 18 Tahun & 8 & 5,3 & 2 & 1,3 \\
\hline 19 Tahun & 31 & 20,6 & 9 & 6,0 \\
\hline 20 Tahun & 55 & 36,7 & 14 & 9,3 \\
\hline 21 Tahun & 19 & 12,7 & 4 & 2,7 \\
\hline 22 Tahun & 7 & 4,7 & 0 & 0 \\
\hline$>23$ Tahun & 1 & 0,7 & 0 & 0 \\
\hline
\end{tabular}

Tabel 4.

Tingkat ansiestas berdasarkan jenis kelamin mahasiswa keperawatan $(n=150)$

\begin{tabular}{c|c|c|c|c}
\hline Variabel & \multicolumn{4}{|c}{ Ansiestas } \\
\hline Jenis & \multicolumn{2}{|c|}{ Normal } & f & $\%$ \\
\cline { 2 - 5 } Kelamin & $\mathrm{f}$ & $\%$ & 4 & 2,6 \\
Laki-laki & 22 & 14,7 & 25 & 16,7 \\
Perempuan & 99 & 66,0 & &
\end{tabular}


Tabel 4 menunjukan bahwa laki-laki yang mengalami ansiestas normal sebanyak $14,7 \%$ dan perempuan sebanyak $66,0 \%$ dan ansiestas ringan $16,7 \%$.

Tabel 5.

Tingkat ansiestas berdasarkan angkatan Mahasiswa keperawatan $(\mathrm{n}=150)$

\begin{tabular}{c|c|c|c|c}
\hline \multirow{2}{*}{ Variabel } & \multicolumn{4}{|c}{ Ansiestas } \\
\hline \multirow{2}{*}{ Angkatan } & \multicolumn{3}{|c}{ Normal } & Ringan \\
\cline { 2 - 5 } & f & $\%$ & 15 & $\%$ \\
\hline 2016 & 64 & 42,7 & 14 & 10,0 \\
2017 & 57 & 38,0 & 9,3 \\
\hline
\end{tabular}

Tabel 5 menunjukan bahwa angkatan 2016 2017 dengan 2 tahun lamanya kuliah 38,0\% dengan 3 tahun lamanya kuliah mendapatkan $42,7 \%$ dengan ansiestas normal dan angkatan mengalamami ansiestas normal.

Tabel 6.

Tingkat ansiestas berdasarkan jumlah partisipasi dalam praktikum $(\mathrm{n}=150)$

\begin{tabular}{c|c|c|c|c}
\hline Variabel & \multicolumn{4}{|c}{ Ansiestas } \\
\hline Jumlah partisipasi & \multicolumn{3}{|c}{ Normal } & Ringan \\
\cline { 2 - 5 } dalam ujian praktek & f & $\%$ & 14 & $\%$ \\
\hline $5-6$ & 62 & 41,3 & 15 & 9,3 \\
$7-8$ & 59 & 39,3 & & 10,0 \\
\hline
\end{tabular}

Tabel 6 menunjukan bahwa frekuensi ansiestas menurut jumlah partisipasi dalam ujian praktek menunjukan hasil bahwa responden yang mempunyai pengalaman ujian praktikum 5-6 mayoritas mengalami ansiestas normal yaitu $41,3 \%$ dan untuk responden yang mengikuti ujian praktek sebanyak 7-8 mayoritas mengalami ansiestas normal.

Tabel 7.

Mekanisme Koping Mahasiswa keperawatan ( $\mathrm{n}=150)$

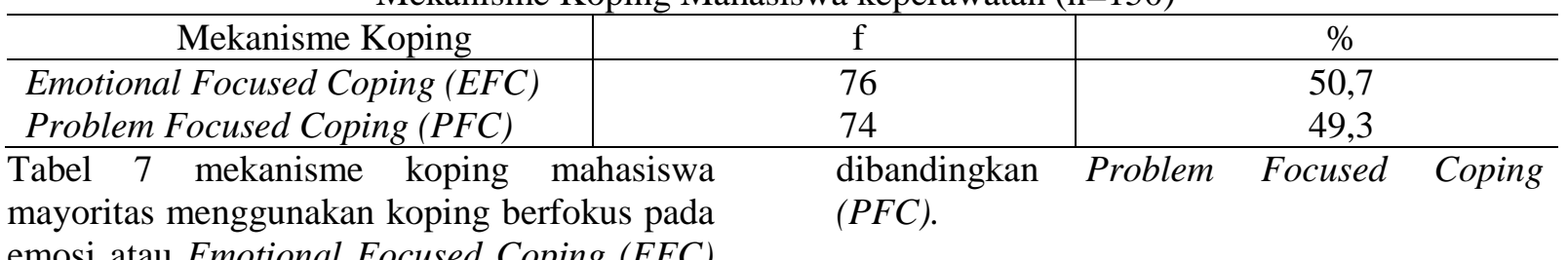

emosi atau Emotional Focused Coping (EFC)

Tabel 8 .

Mekanisme Koping Berdasarkan Usia Mahasiswa keperawatan ( $\mathrm{n}=150)$

\begin{tabular}{l|c|c|c|c}
\hline Variabel & \multicolumn{4}{|c}{ Mekanisme Koping } \\
\hline \multicolumn{1}{c|}{ Usia } & EFC & P & $\%$ \\
\cline { 2 - 5 } & f & $\%, 3$ & 5 & 3,3 \\
18 Tahun & 5 & 13,3 & 20 & 13,3 \\
20 Tahun & 20 & 21,3 & 37 & 24,7 \\
21 Tahun & 32 & 8,7 & 10 & 6,7 \\
22 Tahun & 13 & 3,3 & 2 & 1,3 \\
>23 Tahun & 5 & 0,7 & 0 & 0 \\
\hline
\end{tabular}

Tabel 8 Mekanisme Koping mahasiswa pada usia 20 tahun' mayoritas menggunakan mekanisme koping berfokus pada masalah (PFC) yaitu $24,7 \%$.
Tabel 9 Mekanisme Koping Berdasarkan Jenis Kelamin menunjukan bahwa perempuan lebih banyak menggunakan strategi mekanisme koping PFC $(42,7 \%)$ dan laki-laki lebih banyak menggunakan strategi mekanisme koping EFC. 
Tabel 9.

Mekanisme koping berdasarkan jenis kelamin mahasiswa keperawatan $(\mathrm{n}=150)$

\begin{tabular}{|c|c|c|c|c|}
\hline \multirow{3}{*}{$\begin{array}{c}\text { Variabel } \\
\text { Jenis Kelamin }\end{array}$} & \multicolumn{4}{|c|}{ Mekanisme Koping } \\
\hline & \multicolumn{2}{|c|}{ EFC } & \multicolumn{2}{|c|}{ PFC } \\
\hline & $f$ & $\%$ & $f$ & $\%$ \\
\hline $\begin{array}{l}\text { Laki-laki } \\
\text { Perempuan }\end{array}$ & $\begin{array}{l}16 \\
60\end{array}$ & $\begin{array}{l}10,6 \\
40,0\end{array}$ & $\begin{array}{l}10 \\
64\end{array}$ & $\begin{array}{c}6,7 \\
42,7\end{array}$ \\
\hline
\end{tabular}

Tabel 10.

Mekanisme koping berdasarkan angkatan mahasiswa keperawatan $(\mathrm{n}=150)$

\begin{tabular}{c|c|c|c|c}
\hline \multirow{2}{*}{ Variabel } & \multicolumn{4}{|c}{ Mekanisme Koping } \\
\hline \multirow{2}{*}{ Angkatan } & \multicolumn{2}{|c|}{ EFC } & PFC \\
\cline { 2 - 5 } & $\mathrm{f}$ & $\%$ & 38 & $\%$ \\
\hline 2016 & 41 & 27,3 & 36 & 25,3 \\
2017 & 35 & 23,3 & \\
\hline
\end{tabular}

Tabel 10 Mekanisme Koping Berdasarkan Angkatan menunjukan bahwa angkatan 2016 lebih dominan menggunakan mekanisme koping EFC berbeda dengan angkatn 2017 yang lebih banyak menggunakan mekanisme koping PFC sebanyak 24,0\%.

Tabel 11.

Mekanisme koping berdasarkan jumlah partisipasi dalam ujian praktek mahasiswa keperawatan $(n=150)$

\begin{tabular}{|c|c|c|c|c|}
\hline Variabel & \multicolumn{4}{|c|}{ Mekanisme Koping } \\
\hline \multirow[t]{2}{*}{ Jumlah Partisipasi Dalam Ujian Praktek } & \multicolumn{2}{|c|}{ EFC } & \multicolumn{2}{|c|}{ PFC } \\
\hline & $\mathrm{f}$ & $\%$ & $\mathrm{f}$ & $\%$ \\
\hline $5-6$ & 38 & 25,3 & 38 & 25,3 \\
\hline $7-8$ & 38 & 25,3 & 36 & 24,0 \\
\hline
\end{tabular}

Tabel 11 mekanisme koping berdasarkan jumlah partisipasi dalam ujian menunjukan bahwa partisipan yang mengikuti ujian 7-8 kali yang menggunakan mekanisme koping PFC sebnyak $24,0 \%$.

\section{PEMBAHASAN}

Hasil penelitian ini menunjukan mayoritas responden didominasi oleh remaja akhir yang di dalam hasil penelitian didapatkan usia terbanyak yaitu 20 tahun $(46,0 \%)$. Menurut Notoatmodjodalam Lubis (2013) yang mengemukakan bahwa 13-25 tahun merupakan anak usia remaja, Jahja (2011) mengatakan bahwa usia 19-22 tahun masuk dalam usia remaja akhir yang akan memasuki dalam perkembangan dewasa awal. Usia tersebutmerupakan usia dimana seseorang dapat bersosialisasidan secara psikologis mampu untukmandiri akan tetapi pada usia ini juga adanya perubahan dalam psikologis pada remaja seperti perubahan emosi yang sensitif atau peka misalnya mudah sekali untuk menangis, cemas bahkan mudah untuk bereaksi agresif terhadap gangguan yang mempengaruhinya dan hal ini cenderung sering terjadi pada perempuan. Di dalam penelitian ini didominasi oleh perempuan $82,7 \%$ dibandingkan laki-laki yang menurut penelitian yang dilakukan Wulandari (2012) mengatakan bahwa masyarakat menganggap perawat merupakan profesi yang cocok untuk perempuan dengan konsep gender perempuan dianggap tekun, sabar, dan lemah lembut penelitian ini sejalan dengan penelitian Syahputra (2009) mengatakan proposi perempuan dalam pendidikan keperawatan jauh lebih besar dari pada laki-laki dan sifatsifat yang ada pada perempuan salah satunya caring yang meliputi sikap jujur, sabar, peduli dan menghormati orang lain sehingga dengan sifat tersebut banyak orang beranggapan perawat identik dengan perempuan ( Pambudi \& Wijayanti, 2012)

Dilihat dari angkatan yang lamanya kuliah berkisar 2 tahun dan 3 tahun yang respondennya terbanyak ikut berpartisipasi dalam penelitian ini adalah angkatan 2016 (52.7\%) dengan lamanya kuliah 3 tahun. Populasi yang didapatkan dengan cara purposive sampling di tempat saat dilakukan penelitian dan jumlah pengalaman ujian praktek laboratorium dengan rata-rata 6 kali 
mengikuti ujian praktek yang tidak menentu sesuai angkatan disebabkan ada mahasiswa yang mengambil cuti dan jumlah pengalaman ujian prakteknya terbanyak yaitu 4-5 kali $(50.7 \%)$

Sebagian besar responden di dalam penelitian ini masuk dalam kategori ansiestas normal yang merupakan hal yang pasti untuk terjadi pada beberapa orang akan tetapi tidak berkelanjutan dan perilakunya tidak berlebihan dalam hal mengurangi tekanan tersebut. Hasil ini karenakan oleh sebagian besar usia responden masuk dalam kategori usia remaja akhir memasuki dewasa awal (Tabel 1), Dalam usia remaja menurut Episentrum dalam Lubis (2013) yang adalah masa perubahan yang terjadi secara psikologis yang disebabkan adanya perubahan hormon pada masa remaja dan akhirnya banyak tuntutan dan tekanan yang ditunjukan pada remaja seperti untuk tidak bertindak layaknya anak-anak dan harus lebih mandiri dan bertanggung jawab, ditambah lagi seminggu sebelum dilakukan ujian praktikum laboratorium mahasiswa per individu atau mandiri melakukan simulasi tindakan tersebut dan mahasiswa juga diberikan kisi-kisi tentang materinya dan tentu sebagian besar mahasiswa akan mempersiapkan dirinya dengan belajar, maka dari itu ketika responden diberi ruang untuk melakukan simulasi sebelum ujian dan melakukan tindakan dengan mandiri akan menunjukan bahwa ketika mahasiswa belajar mandiri dengan simulasi dapat mengurangi stres yang pada akhirnya berpengaruh pada performa yang lebih baik ketika melakukan ujian keterampilan (Mills, et al., 2016).

Penelitian ini juga terdapat $19.3 \%$ responden mengalami ansiestas ringan hal ini menunjukan bahwa tidak menutup kemungkinan mahasiswa dapat mengalami ansiestas, ansiestas merupakan kesulitan dan menjadikan hal yang normal dari pengalaman baru, pertumbuhan, perubahan, penemuan identitas dan makna hidup (Saddock 2010) dan mahasiswa FKIK UKSW angkatan 2016 dan 2017 tingkat ansiestas dalam kategori ringan lebih sedikit dibandingansiestas dalam kategori normal berbeda dengan penelitian yang dilakukan oleh Syarifah, S dengan judul Gambaran Tingkat Kecemasan Mahasiswa Keperawatan Saat Menghadapi Ujian Skill Lab di Universitas Islam Negeri Syarif Hidayatulah 2013 di Jakarta yang mendapatkan hasil mahasiswa yang mengalami kecemasan dalam kategori ringan $(50,3 \%)$ lebih banyak dari kecemasan dalam kategori normal $(45,7 \%)$.

Menurut Stuart (2013) ansiestas ringan ini berhubungan dengan ketegangan dalam kehidupan sehari-hari dan membuat seseorang waspada dan memperluas persepsinya, ansiestas ringan ini dapat menjadi motivasi belajar dan menghasilkan kreativitas dan pertumbuhan, perilaku yang ditunjukan seperti sesekali nafas pendek, nadi terasa cepat, muka berkerut, bibir bergetar, konsentrasi pada masalah, menyelesaikan masalah secara selektif, tidak dapat duduk dengan tenang dan ada tremor halus ditangan. Mahasiswa yang mengalami ansiestas ringan masih mempunyai performa dan prestasi yang baik (Colbert-Getz JM, et al., 2013) dan penelitian ini tidak mendapatkan responden mengalami ansiestas sedang ataupun berat yang menurut penelitian Akbar (2015) menjelaskanbahwa jika responden mengalami ansiestas berat tidak dapat berprestasi sebaik responden atau mahasiswa yang mengalami ansiestas rendah.

Hasil data pada tabel 3 menunjukan ansiestas dalam kategori normal dan ringan terbanyak ada pada umur 20 tahun. Distribusi frekuensi ansiestas menurut jenis kelamin untuk kategori ansiestas normal lebih banyak perempuan $(66,0 \%)$ dan juga ansiestas ringan $(16,7 \%)$ dibandingkan laki-laki. Hasil ini sejalan dengan penelitian yang dilakukan oleh Rahmawati (2016) yang dilakukan pada mahasiswa tahun pertama program studi Ilmu Keperawatan juga menunjukan hasil $94,4 \%$ responden perempuan mengalami ansiestas dalam kategori normal hal ini juga dikarenakan responden perempuan yang lebih banyak dibanding laki-laki. Data distribusi frekuensi ansiestas menurut angkatan menunjukan bahwa 42,7\% dari angkatan 2016 dengan lamanya kuliah memasuki tahun ke 3 mengalami ansiestas dalam kategori normal, $10,0 \%$ mengalami ansiestas ringan dan untuk angkatan 201738,0\% mengalami ansiestas normal, 9,3\% mengalamai ansiestas ringan. Jika dilihat dari pengalaman mengikuti ujian praktek responden yang mengalami ansiestas normal terbesar yaitu $41,3 \%$ dengan pengalaman praktek 5-6 kali. 
Sebanyak 50,7\% mahasiswa PSIK menggunakan mekanisme koping berfokus pada emosi (EFC) dimana individu akan mengontrol respon emosionalnya melalui pendekatan tingkah laku dan kognitif (Sarafino, 2012) sementara 49,3\% menggunakan mekanisme koping berfokus pada masalah (PFC) dimana individu akan melakukan sesuatu dengan meminimalisir atau memodifikasikan situasi untuk mengurangi ansiestas (Sarafino, 2012). Penelitian yang dilakukan oleh Fikri, 2016 juga mendapatkan mekanisme koping yang digunakan responden lebih cenderung menggunakan Emotion Focused Coping dengan data 55,4\% dari 224 orang.Nasir dan Muhith (2011) mengemukakan 5 jenisyang digunakan dalam emotional focused coping yaitu yang pertama self-control saat responden berusaha untuk mengatur perasaan ketika menghadapi ujian dengan berkata pada diri sendiri bahwa mereka akan menerima hal baik saja, kedua distancing responden melakukan sesuatu untuk melupakan masalah tersebut dengan menciptakan pandangan-pandangan yang positif terhadap situasi yang tejadi, ketiga positive reappraisal saat rsponden akan mencari makna positif dari permasalahan dan terkadang melibatkan diri dengan hal yang religious seperti mahasiwa PSIK selalu berdoa sebelum melakukan ujian praktek dan mempersiapkan dirinya, keempat Accepting responsibility responden menyadari akan tanggung jawab diri sendiri dalam masalah yang dihadapinya dan menerima untuk membuat semua menjadi lebih baik, dan terakhir escape/avoidance responden mencoba melarikan diri atau mengalihkan dengan cara lain seperti makan atau ngemil.

Nasir dan Muhith (2011) juga mengemukakan 3 jenis mekanisme koping berfokus pada masalah (PFC) yang digunakan oleh 49,3\% responden yaitu Confrontatitive dimana responden mengubah keadaan dengan cara yang cukup agresif seperti mengekpresikan kemarahannya ke orang lain saat merasa terganggu akan tetapi hal ini jarang dilakukan, kedua seeking social support responden mendapatkan bantuan informasi dari orang lain seperti contohnya responden yang didominasi perempuan ini cenderung berkelompok atau mempunyai sahabat dan komunitas sehingga responden atau mahasiswa tersebut saling sharing atau curhat dengan teman-temannya untuk mendapatkan rasa lega atau respon yang positif begitu juga dengan responden laki-laki, ketiga planful problem solving responden dengan hati-hati atau fokus dengan apa yang dilakukan terutama saat ujian, bertahap, dan analitis, mencoba mengubah keadaan yang dianggap menekan menjadi sesuatu yang akan baik-baik saja, didukung oleh teori Hurlock (2009) yang mengatakan bahwa pada akhir masa remaja banyak remaja yang akan melakukan cara-cara untuk mengatasi masalah emotionalnya salah satu dengan cara yaitu latihan fisik, berolahraga, menyibukan diri dengan pekerjaan yang disenangi dan berbagi cerita kepada orang yang dipercayai.

Secara umum hasil penelitian menunjukan bahwa pemilihan dan penggunaan strategi mekanisme koping antara EFC dan PFC hasilnya tidak jauh berbeda ini menunjukan bahwa setiap individu dapat menggunakan kedua strategi tersebut atau salah satu saja, ini dikarenakan EFC maupun PFC mempunyai kelebihan dan kekurangan yang dapat berdampak bagi kemampuan beradaptasi seseorang. Strategi coping yang efektif adalah saat dimana individu menggunakan strategi coping yang sesuai dengan situasi atau jenis stres (Rutter dalam Puspitasari, 2009). Dalam menghadapi ujian responden bisa menggunakan mekanisme koping EFC untuk mengontrol emosinya begitu juga dengan mekanisme koping PFC individu harus melakukan sesuatu untuk dapat menyelesaikan ansiestasnya. Park., et al dalam Bartram (2008) menambahkan bahwa mekanisme koping EFC atau PFC memiliki potensi bersifat adaptif pada situasi cemas.

Tabel 8 dan 9 menunjukan distribusi frekuensi menurut usia mayoritas didominasi oleh respondenberusia 20 tahun $(24,7 \%)$ pada mekanisme koping EFC dan PFC dan menurut lebih banyak didominasi oleh perempuan dengan menggunakan mekanisme koping terbanyak berfokus pada masalah (PFC) sebanyak $42,7 \%$ dan mekanisme berfokus pada emosi (EFC) sebanyak 40,0\%. Dapat dilihat bahwa responden perempuan banyak menggunakan PFC yang dimana PFC cenderung untuk lebih fokus pada masalah kemudian melakukan sesuatu tindakan agar dapat menyelesaikan masalah atau ansiestas. 
Saat menghadapi ansiestas ujian praktek, perempuan tidak bisa menghadapinya hanya dengan menggunakan mekanisme koping EFC untuk mengontrol emosi akan tetapi juga menggunakan koping PFC untuk menyelesaikan ujian praktek tersebut dengan tindakan begitupun sebaliknya dengan lakilaki. Diperkuat oleh penelitian yang dilakukan P. Diah, (2010) menunjukan PFC lebih banyak digunakan oleh perempuan dibanding laki-laki yang dilihat dari hasil mean PFC perempuan 56,00 dan pria 55,70. Sementara untuk responden laki-laki lebih berfokus pada EFC $(10,6 \%)$ sementara PFC $(6,7 \%)$. Hasil sejalan dengan penelitian yang dilakukan Mustofa, 2018 menunjukan pada laki-laki menggunakan koping EFC dengan nilai mean EFC 46,28 dibanding nilai mean PFC 18,51 dalam menghadapi praktikum.

Kemudian jika dilihat dari angkatan menunjukan $27,3 \%$ menjadi persentase terbesar pada angkatan 2016 dengan menggunakan mekanisme koping berfokus pada emosi (EFC) dan presentasi terbesar untuk angkatan 2017 yaitu 24,0\% dengan menggunakan mekanisme koping berfokus pada masalah (PFC). Menurut penelitian Susanti, (2012) didasari oleh pendapat Allen \& Leary, (2010) mengatakan bahwa kematangan individu terhadap kemampuan coping yang tinggi maka akan cenderung menggunakan PFC. Sebaliknya jika kematangan coping seseorang dalam relative rendah maka akan cenderung menggunakan EFC, dalam hasil penelitian ini menunjukan angkatan 2017 yang mempunyai kemampuan coping yang tinggi dibandingkan dengan angkatan 2016. Maka dari itu strategi koping responden PSIK FKIK tidak dapat ditentukan oleh lamanya individu kuliah ataupun mengikuti ujian. Jika dilihat dari pengalaman responden mengikuti ujian praktek didapatkan bahwa tidak ada perbedaan yang sangat jauh antara mahasiswa PSIK yang mengikuti ujian sebanyak 5, 6, 7 dan 8 kali responden cenderung menggunakan mekanimse koping EFC dan PFC.

Ujian praktek laboratorium yang dilakukan mahasiswa PSIK FKIK UKSW merupakan salah satu kegiatan pembelajaran yang wajib untuk diikuti untuk sebagai syarat kelulusan matakuliah tersebut dan responden yang diyakini bahwa didalam pengalaman praktek laboratorium dapat memperkuat teori-teori yang didapatkan sebelumnya (Nursalam, 2012) dan mahasiswa yang dituntut harus lebih bisa mandiri dan bertanggungjawab ini akan terbentuk dengan seiringnya waktu. Menurut Niwana dalam Lubis (2013) bahwa rasa tanggung jawab ini akan dapat dilihat dari kemampuan diri seseorang untuk memahami arti, norma dan nilai-nilai etis tertentu, kemudian berusaha untuk hidup didalamnya, sama halnya dengan bagaimana pentingnya memahami dan merespon ujian praktek laboratorium tersebutsehingga ansiestas tersebut dapat terkendalikan.

\section{SIMPULAN}

Hasil penelitian menunjukan mayoritas responden didominasi oleh perempuan dengan usia terbanyak 20 tahun. Tingkat ansiestas responden menunjukan mayoritas mengalami ansiestas dalam kategori normal sedangkan $19,3 \%$ mengalami ansiestasdalam kategori ringan. Hasil dari data mekanisme koping menunjukan mayoritas responden menggunakan mekanisme koping berfokus pada emosi dan 49,3\% responden menggunakan mekanisme koping berfokus pada masalah.

\section{DAFTAR PUSTAKA}

Arief, S., \& Sumarni. 2013. Hubungan kecemasan menghadapi ujian skills lab modul shock dengan prestasi yang dicapai pada mahasiswa FK Universitas Gajah Mada angkatan 2000. Diakses dari

http://www.ebookspdf.org/download/k ecemasan.html. tgl akses 18 Nov 2018

Akbar, D. 2015.Hubungan Antara Tingkat Kecemasan dengan PrestasiAkademik Mahasiswadi Fakultas Psikologis. UniversitasMuhammadiyah Surakarta. Skripsi. Naskah Publikasi.

Allen, A.B., \& Leary, R.M. (2010). Selfcompassion, Stress \& Coping. Social and Personality Psychology Compass. 4/2, 107-118.

Basuki, I., \& Hariyanto. 2015. Asesment Pembelajaran. Remaja Rosdakarya Offset: Bandung. 
Bartram, D \& Gardner, D. 2008. Coping With Stress. In Practice, Vol 30, 228-231.

Colbert - Getz JM. (2013). How do gender and anxiety affect students'self assasment and actual performance on a high - stakes clinical skills examination?.Academic Medicine; 88(1): $44-8$.

Dardas, A., \& Ahmad M. (2013). Psychometric Properties of the Parenting Stress Index with Parents of Children with Autistic Disorder. Journal of Intellectual Disability Research. Vol 4 (1), 62-72

Depkes RI. 2013. Hasil Riskesdas. Dapartermen Kesehatan Republik Indonesia. Diakses dari http://www.depkes.go.id/article/print/16 100700005/peran- keluargadukung-kesehatan-jiwamasyarakat.html, tgl akses 19 Nov 2018

Essau, A, Sasagawa. S., Ishikawa, S. (2010).Early Learning Lxperience and Adolescent Anxiety: A Ross-cultural Comparison Between Japan and England, 20 (1), 196-204.

Fikri, L. 2016. Hubungan Tingkat Spiritualitas Dengan Tingkat Kecemasan dan Mekanisme Koping Mahasiswa Tingkat Pertama FKIK UMY 205/2016. Universitas Muhammadiyah Yogyakarta. Diakses dari http://repository.umy.ac.id/handle/123 456789/7320?show=full, tgl akses 28 Juni 2019

Hurlock, B. 2009. Psikologi Perkembangan: Suatu Perkembangan Sepanjang Rentan Kehidupan. Jakarta: Erlangga.

\section{Jahja, Y. 2011.Psikologi Perkembangan.Jakarta: Kencana}

Kaplan, H., Saddock, B., Grebb, JA. 2010. Sinopsis Psikiatri Ilmu Pengetahuan PerilakuPsikiatri Klinis. Tanggerang: Bina Rupa Aksara.
Keliat, Budi Anna dkk. 2011. Manajemen Kasus Gangguan Jiwa. Jakarta: EGC: CMHN.

Lubis, L. 2013. Psikologi Kespro: Wanita \& Perkembangan Reproduksinya. (Edisi Pertama). Jakarta: Kencana Prenada Media Group.

Mustofa, I. 2018. Coping Stress Mahasiswa Praktikan Ditunjau Dari Jenis Kelamin. Skripsi. Universitas Muhammadiyah Surakarta. Diakses dari http://eprints.ums.ac.id/66442/2/HAL AMAN\%20DEPAN.pdf, tgl akses 01 Agustus 2019

Mills, B., Carter, O., Ross, N., Quick, J., \& Reid, C. (2016). The Contribution of Instuctor Presence To Social Evaluation Anxiety, Immersion And Performance Within SimulationBased Learning Environmrnts: A With In - Subject Randomised Cross Over Trial With Paramedic Students (Abstract). Australian Journal of Paramedicine. Vol 13 (2).

Nasir, A., \& Abdul, M. 2011. Dasar- Dasar Keperawatan Jiwa. Jakarta: Salemba Medika.

Nursalam. 2012. Manajemen Keperawatan:Aplikasi dalam Praktik Keperawatan Profesional. (Edisi Ketiga). Jakarta: Salemba Medika

Nursalam. (2013).Konsep Penerapan Metode Penelitian Ilmu Keperawatan. Jakarta: Salemba Medika

Nanda. (2015).Definisi \& Klasifikasi 20152017. alih bahasa: Budi Anna Kelliat,et al. (Edisi 10). Jakarta: EGC

Oli, F. 2013. Mekanisme Koping Dalam Mengatasi Stres Pada Mahasiswa Akademi Keperawatan Departemen Kesehatan RI Tingkat Satu. Universitas Teuku Umar:Skripsi.MeulabohAceh Barat.

Potter dan Perry. 2010. Fundamental Keperawatan. (Edisi Kedua). Jakarta: Salemba Medika. 
Pambudi \& Wijayanti. 2012. Hubungan Konsep Diri dengan Prestasi Akademik pada Mahasiswa Keperawatan. Undip. Skripsi. Semarang: Universitas Diponegoro.

Puspitasari, EP. 2009. Peran Dukungan Keluarga Pada Penanganan Penderita Skizofrenia. Skripsi. Universitas Muhammadiyah Surakarta. Surakarta.

P.Diah, M. (2010). Perbedaan Problem Focused Coping Dalam Menghadapi Masalah Pada Pria dan Wanita Yang Menjalani Pacaran Jarak Jauh Di Masa Dewasa Awal. Skripsi. Universitas Sanata Dharma. Yogyakarta. Diakses dari https://repository.usd.ac.id/28788/, tgl akses 01 Agustus 2019.

Rafiki, D. 2017. Hubungan Tingkat Kecemasan Dengan Mekanisme Koping Menghadapi Objective Structured Clinical Examination (Osce) Mahasiswa Semester Ii Stikes Jenderal Achmad Yani. Stikes Jenderal Achmad Yani. Yogyakarta. Diakses pada darihttp://repository.unjaya.ac.id/2203/, tgl akses 18 Nov 2018

Rahmawati. 2016. Hubungan Kecerdasan Emosional Dengan MekanismeKoping Pada Mahasiswa Tahun Pertama Program Studillmu Keperawatan. Universitas Muhammadiyah Yogyakarta. Diakses dari http://repository.umy.ac.id/handle/123 456789/6871, tgl akses 18 Juli 2019

Sholeh, M. 2012.Terapi Shalat Tahajud Menyembuhkan Berbagai Penyakit. Jakarta: PT Mizan Publik.

Syarifah, S. 2013.Gambaran TIngkatan Mahasiswa Keperawatan Saat Menghadapi Ujin Skill Lab. Universitas Islam Negeri Syarif Hidayatullah. Skripsi. Jakarta. Diakses dari http://repository.uinjkt.ac.id/dspace/bit stream/123456789/25674/1/SITI\%2 0NURUS\%20SYARIFAH\%20\%20fkik.pdf, tgl akses 18 Nov 2018
Sjahrir, H. 2008. Nyeri Kepala dan Vertigo. Jogjakarta: Pustaka Cendekia Press

Stuart, W. \& Laraia, T. 2005. Principles and Practice of PsychiatricNursing, 8th edition. St. Louis: Mosby.

Syahputra, N. 2009. Hubungan Konsep Diri Dengan Prestasi Akademik Mahasiswa SI Keperawatan Semester III Kelas Ekstensi PSIK FK USU Medan.Skripsi. USU Institusional Repository. Diaskes dari

http://repository.usu.ac.id/handle/1234 56789/14291, tgl akses 29 Juli 2019.

Saam, Z \& Wahyuni, S. 2012. Psikologi Keperawatan. Cetakan I. Jakarta: PT Raja Grafindo Persada

Sadock, J \& Sadock, A. 2010. Kaplan dan Saddock Buku Ajar Psikiatri Klinis. (Edisi Kedua). Jakarta: EGC

Wulandari, P. 2012. Kesetaraan Gender Perawat Laki-Laki \&Perawat Perempuan Dalam Pelayanan Kesehatan, Universitas Negeri Yogyakarta. Diakses dari http://eprints.uny.ac.id/24800/1/Tiyan \%20Ika\%20Puji\%20Wulandari\%20074 13244004.pdf, tgl akses 22 Juli 2019. 
Jurnal Keperawatan Jiwa Volume 7 No 2 Hal 215 - 226, Agustus 2019

FIKKes Universitas Muhammadiyah Semarang bekerjasama dengan PPNI Jawa Tengah 